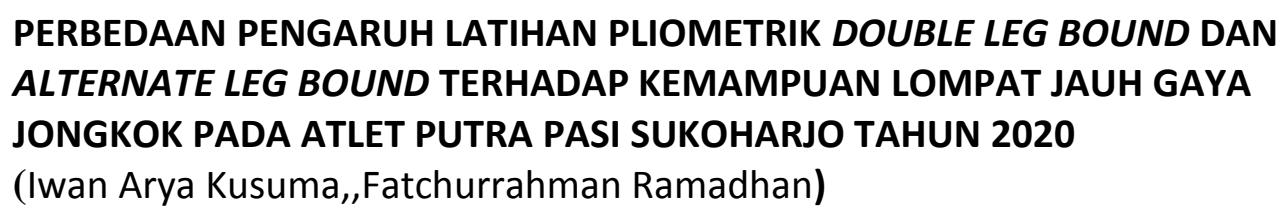

\title{
PERBEDAAN PENGARUH LATIHAN PLIOMETRIK DOUBLE LEG BOUND DAN ALTERNATE LEG BOUND TERHADAP KEMAMPUAN LOMPAT JAUH GAYA JONGKOK PADA ATLET PUTRA PASI SUKOHARJO TAHUN 2020
}

\author{
Iwan Arya Kusuma ${ }^{1}$,Fatchurrahman Ramadhan ${ }^{2}$ \\ Iwan arya@gmail.com \\ Universitas Tunas Pembangunan Surakarta
}

\begin{abstract}
ABSTRAK
Tujuan Penelitian untuk mengetahui Pengaruh latihan pliometrik double leg bound dan alternate leg bound terhadap peningkatan kemampuan lompat jauh gaya jongkok, dan Kemampuan lompat jauh gaya jongkok atlet putra pada PASI Sukoharjo tahun 2020.

Penelitian ini dilaksanakan di PASI Sukoharjo dengan jumlah 30 siswa. Pengambilan sampel menggunakan teknik purposive sampling. Desain penelitian ini menggunakan pretest-posttest design. Metode analisis data yang digunakan adalah uji normalitas, uji homogenitas, dan uji perbedaan. Hasil analisis data maka simpulan diperoleh : (1) Ada Perbedaan pengaruh latihan pliometrik doubleleg bound dengan latihan pliometrik alternate leg boundterhadap kemampuan lompat jauh gaya jongkokpada atletputra PASI Sukoharjotahun 2020, dengan nilai perhitungan thit 2.434 >ttabel2.145 pada taraf signifikasi 5\%. (2) Latihan pliometrik alternate leg bound lebih baik pengaruhnya daripada latihan pliometrik double leg bound kemampuan lompat jauh gaya jongkok pada atlet putra PASI Sukoharjo tahun 2020. KelompokI (kelompok yang mendapat perlakuan pliometrik alternate leg bound) memiliki peningkatan sebesar $9.933 \%$. Sedangkan kelompok 2 (kelompok yang mendapat latihan pliometrik double leg bond memiliki peningkatan sebesar $3.250 \%$.
\end{abstract}

Kata Kunci: Pliometrik Double Leg Bound, Alternate Leg Bound, Lompat jauh

\section{PENDAHULUAN}

Atletik merupakan cabang olahraga tertua di dunia. Gerakan atletik telah dilakukan oleh manusia sejak jaman purba. Dapat dikatakan bahwa, sejak adanya manusia di muka bumi atletik sudah ada, karena gerakan-gerakan yang terdapat dalam cabang olahraga atletik, seperti berjalan, berlari, melompat dan melempar adalah gerakan yang dilakukan oleh manusia di dalam kehidupan sehari-hari.

Cabang olahraga atletik dikenal sejak jaman penjajahan Belanda, namun kurang dikenal oleh masyarakat Indonesia. Hal ini karena olahraga atletik hanya 


\section{PERBEDAAN PENGARUH LATIHAN PLIOMETRIK DOUBLE LEG BOUND DAN ALTERNATE LEG BOUND TERHADAP KEMAMPUAN LOMPAT JAUH GAYA JONGKOK PADA ATLET PUTRA PASI SUKOHARJO TAHUN 2020 \\ (Iwan Arya Kusuma,,Fatchurrahman Ramadhan)}

dilakukan di lingkungan sekolah dan kemiliteran Belanda (Yudha M. Saputra, 2001: 4). Seiring dengan perkembangan dan kemajuan jaman, cabang olahraga atletik mengalami perkembangan yang cukup pesat. Atletik dijadikan induk dari semua cabang olahraga dan dijadikan salah satu mata pelajaran wajib dalam pendidikan jasmani. Menurut Yoyo Bahagia, Ucup Yusuf dan Adang Suherman (1999/2000: 1) bahwa, "Atletik merupakan salah satu mata pelajaran wajib di sekolah-sekolah, karena atletik merupakan mother atau ibu dari semua cabang olahraga".

Cabang olahraga atletik merupakan salah satu bagian latihan yang dioptimalkan melalui program latihan di club olahraga atletik termasuk club PASI Sukoharjo. Salah satu nomor cabang olahraga atletik yang dilatih kepada atlet yaitu Lompat jauh. lompat merupakan salah satu aktivitas pengembangan kemampuan daya gerak atlet yaitu bertindak melakukan suatu bentuk gerakan dengan anggota badannya secara lebih terampil. Seperti dikemukakan Toho Cholik dan Rusli Lutan (2001: 99-100) bahwa, "Melompat pada prinsipnya adalah kemampuan memindahkan suatu objek melalui udara dengan menggunakan tungkai". Nomor lompat yang dilatihkan di club PASI Sukoharjo adalah salah satu di antaranya lompat jauh. Lompat jauh terbagi menjadi tiga macam gaya yaitu gaya seet down in the air atau gaya jongkok, gaya snaiper atau gaya melenting, gaya wolking in the air atau berjalan diudara.

Lompat jauh gaya jongkok merupakan salah satu gaya lompat jauh yang dilatihkan kepada atlet klub PASI Sukoharjo, karena gaya ini lebih mudah dan sederhana dibandingkan gaya melenting atau berjalan diudara.Disebut gaya jongkok, karena gerakan saat melayang diudara harus benar- benar menyerupai orang jongkok atau duduk diudara.

Ditinjau dari gerakan lompat jauh, tungkai dan kaki merupakan bagian tubuh yang dominan untuk gerakan melompat sejauh-jauhnya. Pada saat gerakan lompat jauh, otot-otot tungkai dikerahkan secara maksimal dan pada akhir gerakan melompat dan diakhiri pendaratan dengan kaki dijulurkan 


\section{PERBEDAAN PENGARUH LATIHAN PLIOMETRIK DOUBLE LEG BOUND DAN ALTERNATE LEG BOUND TERHADAP KEMAMPUAN LOMPAT JAUH GAYA JONGKOK PADA ATLET PUTRA PASI SUKOHARJO TAHUN 2020 \\ (Iwan Arya Kusuma,,Fatchurrahman Ramadhan)}

kedepan. Untuk melompat sejauh-jauhnya, maka harus mengerahkan power otot tungkai dengan teknik yang benar.Tamsir Riyadi (1985: 133) menyatakan, "Unsur-unsur yang diperlukan dalam lompat jauh di antaranya daya ledak, kekuatan, kecepatan, koordinasi, kelincahan dan lain-ain". Sedangkan Harsono (1988: 200) berpendapat, "Power terutama penting untuk cabang-cabang olahraga dimana atlet harus mengerahkan tenaga yang eksplosif seperti nomornomor atletik dan juga pada cabang-cabang olahraga yang mengharuskan atlet menolak dengan kaki seperti pada nomor-nomor lompat dalam atletik, sprint, voli dan lain-lain".

Power otot tungkai merupakan bagian penting dalam gerakan lompat jauh. Upaya meningkatkan kemampuan power otot tungkai harus dilakukan latihan secara sistematis dan kontinyu. Radcliffe \& Farentinos (1985, Chu, 1992) dalam penelitian Sarwono (1994: 2) menyatakan, "Pliometrik merupakan salah satu cara atau metode yang sangat baik untuk meningkatkan explosive power". Secara umum latihan pliometrik memiliki aplikasi yang sangat luas dalam kegiatan olahraga, dan secara khusus latihan pliometrik sangat bermanfaat untuk meningkatkan power. Latihan pliometrik pada prinsipnya didasarkan praperegangan otot yang terlibat pada saat tahap penyelesaian atas respon untuk penyerapan kejutan dari ketegangan yang dilakukan otot sewaktu bekerja. Sebagai metode latihan fisik latihan pliometrik dapat dibedakan menjadi tiga kelompok latihan yaitu: latihan untuk anggota gerak bawah, latihan untuk batang tubuh, dan latihan untuk anggota gerak atas.

Berdasarkan bagian-bagian latihan dari pliometrik tersebut, latihan pliometrik untuk meningkatkan power otot lengan yaitu, latihan pliometrik tubuh bagian bawah. Latihan pliometrik tubuh bagian atas pada prinsipnya terdiri tiga macam. Dari bentuk-bentuk latihan pliometrik tubuh bagian atas tersebut dapat diterapkan ke dalam berbagai macam cabang olahraga khususnya yang membutuhkan kinerja dari otot-otot tubuh bagian bawah secara maksimal dan ekplosif. Bentuk latihan pliometrik yang akan dikaji dan diteliti untuk 


\section{PERBEDAAN PENGARUH LATIHAN PLIOMETRIK DOUBLE LEG BOUND DAN ALTERNATE LEG BOUND TERHADAP KEMAMPUAN LOMPAT JAUH GAYA JONGKOK PADA ATLET PUTRA PASI SUKOHARJO TAHUN 2020 \\ (Iwan Arya Kusuma,,Fatchurrahman Ramadhan)}

meningkatkan power otot tungkai yaitu, double leg bound dan alternate leg bound. Dari kedua bentuk latihan pliometrik tersebut belum diketahui bentuk latihan mana yang lebih baik pengaruhnya terhadap peningkatan power otot tungkai, sehingga dapat membantu pencapaian prestasi lompat jauh gaya jongkok. Untuk mengetahui hal tersebut maka perlu dikaji dan diteliti secara lebih mendalam baik secara teori maupun praktek melalui penelitian eksperimen.Latihan pliometrik double leg bound dan alternate leg bound dieksperimenkan pada atlet putra PASI Sukoharjo tahun 2020. Ditinjau pelaksanaan latihan club atletik di PASI Sukoharjo termasuk cabang olahraga atletik khususnya lompat jauh gaya jongkok berjalan dengan baik. Namun kemampuan lompat jauh gaya jongkokpara atlet masih rendah dan perlu ditingkatkan.

Berdasarkan program latihan atletik PASI Sukoharjo bahwa, setiap satu pertemuan program latihan diberi alokasi waktu 120 menit dengan pembagian pemanasan, inti dan pendinginan. Dari waktu yang disediakan tersebut belum dapat digunakan meningkatkan kemampuan lompat jauh gaya jongkok, jika tidak ditunjang atau ditambah latihan di luar jam jam latihan. Memberikan latihan di luar jam latihan merupakan salah satu usaha untuk meningkatkan kemampuan lompat jauh gaya jongkok. Selama ini belum pernah dilakukan latihan di luar jam latihan pada siswa putra PASI Sukoharjo tahun pelajaran 2020, khususnya latihan untuk meningkatkan power otot tungkai. Melalui latihan di luar jam latihan dapat ditingkatkan faktor-faktor yang dapat mendukung pencapaian prestasi lompat jauh gaya jongkok.Dengan memberikan latihan power otot tungkai, maka dapat mendukung pencapaian prestasi lompat jauh gaya jongkoklebih maksimal. Jika atlet memiliki kemampuan lompat jauh gaya jongkokyang baik, maka dapat dijadikan duta atlet atletik dari klub PASI Sukoharjo untuk mengikuti event-event seperti lomba multy event dan single event sehingga mempunyai peluang mencapai prestasi yang semaksimal mungkin. Namun selama ini belum pernah 


\section{PERBEDAAN PENGARUH LATIHAN PLIOMETRIK DOUBLE LEG BOUND DAN ALTERNATE LEG BOUND TERHADAP KEMAMPUAN LOMPAT JAUH GAYA JONGKOK PADA ATLET PUTRA PASI SUKOHARJO TAHUN 2020 \\ (Iwan Arya Kusuma,,Fatchurrahman Ramadhan)}

atlet dari PASI Sukoharjo mengikuti perlombaan atletik khususnya lompat jauh pada event ASEAN GAMES.

Upaya meningkatkan kemampuan power otot tungkai atlet putra PASI Sukoharjo tahun 2020, dapat diberikan latihan pliometrik double leg bound dan alternate leg bound. Latihan pliometrik double leg bound dan alternate leg bound merupakan bentuk latihan untuk meningkatkan power otot tungkai, namun belum diketahui latihan pliometrik mana yang lebih baik pengaruhnya terhadap peningkatan kemampuan lompat jauh gaya jongkok.

\section{KAJIAN TEORI}

\section{Hakikat Latihan}

Latihan merupakan suatu proses yang dilakukan secara teratur guna mencapai tujuan yang telah ditetapkan. Tujuan utama latihan dalam olahraga prestasi adalah untuk mengembangkan kemampuan biomotorik ke standart yang paling tinggi, atau dalam arti fisiologis atlet berusaha mencapai tujuan perbaikan sistem organisme dan fungsinya untuk mengoptimalkan prestasi atau penampilan olahraganya. Berkaitan dengan latihan A. Hamidsyah Noer (1996: 6) menyatakan, "Latihan suatu proses yang sistematis dan kontinyu dari berlatih atau bekerja yang dilakukan dengan berulang-ulang secara kontinyu dengan kian hari kian menambah jumlah beban latihan untuk mencapai tujuan". Menurut Yusuf Adisasmita dan Aip Syarifuddin (1996:145) bahwa, "Latihan adalah proses yang sistematis dari berlatih yang dilakukan secara berulang-ulang, dengan kian hari kian menambah jumlah beban latihan serta intensitas latihannya". Menurut Yusuf Adisasmita dan Aip Syarifuddin (1996: 145) bahwa, "Latihan adalah proses yang sistematis dari berlatih yang dilakukan secara berulang-ulang, dengan kian hari kian menambah jumlah beban latihan serta intensitas latihannya". Menurut Bompa (1990: 3) bahwa, "Latihan merupakan aktivitas olahraga yang sistematik dalam waktu yang lama, ditingkatkan secara progresif dan indicidual yang mengarah pada ciri-ciri fungsi fisiologis dan psikologis manusia untuk mencapai sasaran yang telah ditentukan". Hal senada dikemukakan Russel R. Pate., Bruce 


\section{PERBEDAAN PENGARUH LATIHAN PLIOMETRIK DOUBLE LEG BOUND DAN ALTERNATE LEG BOUND TERHADAP KEMAMPUAN LOMPAT JAUH GAYA JONGKOK PADA ATLET PUTRA PASI SUKOHARJO TAHUN 2020 \\ (Iwan Arya Kusuma,,Fatchurrahman Ramadhan)}

Mc. Clenaghan \& Robert Rotella (1993: 317) bahwa, "Latihan dapat didefinisikan sebagai peran serta yang sistematis dalam latihan yang bertujuan untuk meningkatkan kapasitas fungsional fisik dan daya tahan latihan".

\section{Latihan Plaiometrik}

Pelatihan fisik memegang peranan sangat penting dalam kegiatan olahraga. Selain bertujuan untuk meningkatkan kondisi fisik, program pelatihan fisik merupakan program penting dalam pembinaan atlet untuk berprestasi dalam cabang olahraga yang dijalani.Untuk mencapai prestasi perlu dukungan unsur-unsur yang diperlukan dalam gerakan atau keterampilan dalam suatu cabang olahraga.Atas dasar uraian di atas maka pelatihan kondisi fisik perlu direncanakan secara sistematik serta tepat sasaran.

Plaiometrik berasal dari kata bahasa yunani "pleytuein" berarti memperbesar atau meningkatkan, atau dari akar kata bahasa yunani "plio" dan "metric". Masing masing berarti "lebih banyak" dan "ukuran" (Chu, 1983: Gambetta, 1981; Wilt \& Ecker, 1970). Sekarang ini plaiometrik ditandai dengan kontraksi kontraksi otot yang kuat sebagairespon terhadap pembebanan yang cepat dan dinamis, atau peregangan otot otot yang terlibat.

Gerakan pliometrik dilakukan dalam berbagai cabang olahraga yang menggunakan power, Misalnya linamen pada sepakbola amerika yang keluar dari kedudukannya, pemain voli yang melakukan lompatan melampaui net untuk memblokade pengembalian bola, pelompat yang tinggi yang melompat tinggi melejit keatas, pemain yang memukul bola dan lain-lain. Olahraga dapat dilakukan dengan lebih terampil ika atlet memiliki power yang merupakan gabungan daripada kecepatan dan kekuatan. Plaiometrik merupakan salah satu cara terbaik untuk mengembangkan power ekplosif untuk berbagai cabang olahraga.

Pengorganisasian latihan plaiometrik mengikuti konsep rangkaian latihan power, sebagian besar latihan plaiometrik adalah gerakan yang banyak dibagian tungkai dan pinggul, karena kelompok otot ini adalah merupakan pusat gerakan 
(Iwan Arya Kusuma,,Fatchurrahman Ramadhan)

power olahraga dan memiliki keterlibatan utama dengan semuacabang olahraga. Gerakan plaiometrik dirancang untuk menggerakkan otot pinggul dan tungkai, dan gerakan otot secara khusus yang dipengaruhi oleh bounding, hopping, jumping, leaping, skiping, swinging dan ricocet.

\section{a. Bounding}

Bounding adalah suatu gerakan yang menekankan pada loncatan untuk mencapai ketinggian maksimum dan juga horisontal. Bounding baik dilakukan dengan dua kaki secara bersamaan atau dengan menggunakan salah satu kaki secara bergantian.

\section{b. Hopping}

Hopping terutama menekankan pada Ioncatan untuk mencapai ketinggian maksimum kearah vertikal dan kecepatan maksimum gerakan kaki, yakni mencapai jarak horisontal dengan tubuh.

\section{c. Jumping}

Mencapai ketinggian maksimum juga diperlukan dalam jumping, sedangkan kecepatan pelaksanaan merupakan faktor kedua. Jarak horisontal tidak diperlukan dalam jumping. Jumping dapat dilakukan dengan dua kaki ataupun dengan satu kaki.

\section{d. Leaping}

Leaping adalah suatu latihan kerja tunggal yang menekankan jarak horisontal dan kecepatan maksimum, leaping dapat dilakukan dengan stu atau dua kaki.

\section{e. Skipping}

Skipping dilakukan dengan cara meloncat-loncat secara bergantian. Skipping menekankan ketinggian dan jarak horisontal.

\section{f. Ricocet}

Ricocet semata-mata menekankan pada tingkat kecepatan tungkai dan gerakan kaki, meminimalkan jarak vertikan dan horisontal yang memberikan kecepatan pelaksanaan yang lebih tinggi. 
(Iwan Arya Kusuma,,Fatchurrahman Ramadhan)

\section{g. Swingging}

Swingging merupakan gerakan togok yang bersifat menyamping, horisontal dan vertikal, dengan melibatkan otot sekunder pada bahu, dada, dan lengan. Dalam kebanyakan olahraga,

\section{h. Twisting}

Twisting didefinisikan sebagai gerakan putaran dan atau menyamping dari togok tanpa melibatkan bahu atau lengan. Dalam kebanyakan olahraga, hasil ahkir dari power dibangkitkan oleh pinggul, tungkai dan ditransfer melalui togok sebagai gerakan yang melibatkan dada, bahu, punggung dan lengan. Dengan demikian, gerakan-gerakan seperti melempar, menarik, mendorong dan mengangkat serta mengayun merupakan aktifitas utama tubuh bagian atas, namun analisis juga menyatakan bahwa togok, pinggul dan tungkai juga memainkan peran yang penting untuk menyangga dan mentransfer beban dan memberikan keseimbangan. Mempercayai bahwa lemparan, pukulan, passing, dan ayunan semuanya saling terikat dengan berbagai kelompok otot tubuh bagian atas.

\section{Latihan plyometrics double leg bound}

Latihan plyometrics yang dilakukan untuk meningkatkan power otot tungkai harus bersifat khusus yaitu latihan yang ditujukan untuk pinggul dan tungkai (Radcliffe dan Farentinos : 15 - 19). Sebagian besar gerakan olahraga berasal dari pinggul dan tungkai, misalnya gerakan lari, lempar, dan lompat. Banyak energi gerakan yang dibangkitkan oleh pingul dan tungkai, kemudian ditransfer ke atas melalui togok dengan menekuk, merentang atau memutar dan akhirnya diterima oleh tubuh bagian atas untuk melakukan beberapa jenis ketrampilan gerak yang melibatkan bahu, dada dan lengan.

Menurut Radcliffe \& Farentinos dalam M. Furqon dan M. Douwes (2002:28) "Bentuk latihan double leg bound mengembangkan power otot-otot tungkai dan pinggul, khususnya gluteal, hamstrings, quadriceps, dan gastrocnemius". Otot-otot lengan dan bahu secara tidak langsung juga terlibat. 


\section{PERBEDAAN PENGARUH LATIHAN PLIOMETRIK DOUBLE LEG BOUND DAN ALTERNATE LEG BOUND TERHADAP KEMAMPUAN LOMPAT JAUH GAYA JONGKOK PADA ATLET PUTRA PASI SUKOHARJO TAHUN 2020 \\ (Iwan Arya Kusuma,,Fatchurrahman Ramadhan)}

Latihan ini memiliki aplikasi yang luas untuk berbagai cabang olahraga yang melibatkan lompat/loncat, lari, angkat besi, dan renang. Latihan ini dimulai dengan posisi half-squat dengan lengan berada di samping badan bahu condong ke depan melebihi posisi lutut, punggung lurus serta pandangan ke depan. Pelaksanaan gerakan ini dengan meloncat ke depan dan ke atas, menggunakan ekstensi pinggul dan gerakan lengan untuk mendorong ke depan. Diusahakan untuk mencapai ketinggian dan jarak maksimum dengan posisi tubuh tegak. Hal ini agar hasilnya dapat maksimal. Dibawah ini disajikan latihan bounding bentuk double leg bound.

Latihan plyometrics double leg bound menggunakan dua tumpuan kaki dalam melakukan loncatan kedepan atas. Ekstensi pinggul dan ayunan lengan dalam latihan double leg bound sangat mempengaruhi sekali dalam menentukan jauhnya lompatan. Pelaksanaan latihan plyometrics double leg bound mempunyai kelebihan antara lain : gerakan melompat dengan meggunakan dua kaki tumpu tinggi jauh kedepan memberikan manfaat pada saat melakukan gerakan pendaratan. Pada pendaratan posisi tubuh bisa seimbang. Hal ini menguntungkan pelompat jauh saat diambil ukuran jarak lompatannya yang menjadi bertambah karena pendaratan yang benar.

\section{Latihan plyometrics alternate leg bound}

Bentuk latihan alternate leg bound hampir sama dengan latihan double leg bound, untuk mengembangkan power tungkai dan pinggul. Latihan ini menggunakan satu kaki tumpu dalam melakukan loncatan. Dengan mengubah kedua tungkai khususnya kerja flexors dan extensors paha dan pinggul, maka latihan ini digunakan untuk meningkatkan lari, langkah, dan gerakan lari cepat.( Radcliffe dan Farentinos 1985:31).

Tahap lari awalan dalam lompat jauh sangat diperlukan, karena tahap lari merupakan tahap pertama dari serangkaian gerakan dalam lompat jauh. Dengan demikian latihan alternate leg bound sesuai untuk cabang olahraga lompat jauh. 
(Iwan Arya Kusuma,,Fatchurrahman Ramadhan)

Latihan ini dimulai dengan sikap berdiri yang enak dengan salah satu kaki agak di depan untuk memulai melangkah, lengan relaks di samping badan. Pelaksanaan gerakan ini dengan tolakan tungkai belakang, gerakan lutut ke dada dan usahakan loncatan setinggi dan sejauh mungkin sebelum mendarat. Kemudian bentangkan kaki ke depan dengan cepat dan ayunkan kedua lengan. Ulangi rangkaian ( dengan kaki lain ) pada saat mendarat. Jarak yang dtempuh 10 meter. Gerakan dengan satu kaki yang dilakukan dengan kuat dan cepat menghasilkan lompatan yang tinggi dan jauh. Latihan dengan satu kaki yang dilakukan dengan kuat dan cepat ini dapat meningkatkan power otot tungkai sehingga dapat berpengaruh terhadap lompat jauh. Hal yang perlu diperhatikan dalam latihan alternate leg bound juga masalah berat badan. Kelebihan berat badan akan mengurangi kecepatan kontraksi otot sehingga akan mengurangi kecepatan gerak.

Pelaksanaan latihan plyometrics alternate leg bound mempunyai kelebihan antara lain : gerakan melompat dengan satu kaki yang tinggi dan jauh kedepan memberikan manfaat yang sangat besar pada saat melakukan gerakan melayang diudara, sehingga posisi badan saat diudara bisa bertahan lebih lama. Dengan posisi badan yang melayang lebih lama diudara, maka jarak lompatan juga semakin jauh.

\section{Lompat Jauh}

\section{a. Pengertian lompat jauh}

Lompat jauh adalah merupakan salah satu nomor lompat dalam cabang olahraga atletik. Tujuan lompat jauh adalah melompat untuk mencapai jarak lompatan kedepan yang sejauh-jauhnya pada bak pasir. Untuk mencapai jarak lompatan yang sejauh-jauhnya perlu dikuasai unsur teknik dan fisik yang mendukung. Menurut Aip Syarifuddin (1992:90) mengemukakan bahwa, “ Lompat jauh adalah suatu bentuk gerakan melompat mengangkat kaki ke atas dan kedepan dalam upaya membawa titik berat badan selama mungkin di 


\section{PERBEDAAN PENGARUH LATIHAN PLIOMETRIK DOUBLE LEG BOUND DAN ALTERNATE LEG BOUND TERHADAP KEMAMPUAN LOMPAT JAUH GAYA JONGKOK PADA ATLET PUTRA PASI SUKOHARJO TAHUN 2020 \\ (Iwan Arya Kusuma,,Fatchurrahman Ramadhan)}

udara (melayang diudara) yang dilakukan dengan cepat dan dengan jalan melakukan tolakan pada satu kaki untuk mencapai jarak yang sejauh-jauhnya"

Lompat jauh memiliki tiga macam gaya yaitu gaya jongkok, berjalan diudara dan schnaper. Tamsir Riyadi (1985:95) mengemukakan pendapat bahwa, " Dalam lompat jauh terdapat tiga macam gaya yaitu gaya jongkok, gaya tegak (schnapper) dan gaya berjalan diudara." Dalam penelitian ini gaya yang digunakan adalah gaya jongkok karena gaya ini paling mudah dilakukan terutama bagi anak-anak sekolah. Perlu diketahui bahwa yang menyebabkan adanya perbedaan dari ketiga gaya tersebut sebenarnya hanya terletak pada saat melayang diudara saja. Jadi yang menyebabkan perbedaan dari ketiga gaya dalam lompat jauh hanya terdapat pada saat melayang. Pada saat melayang diudara keseimbangan perlu diperhatikan agar dapat memaksimalkan jauhnya lompatan dan mempersiapkan pendaratan yang benar. Dari pendapat yang telah dikemukakan diatas tersebut jelaslah bahwa gaya dalam lompat jauh dilakukan pada saat melayang diudara.

Dari sini dapat diketahui bahwa ada berbagai teknik atau gaya yang dilakukan dalam lompat jauh sebagai usaha untuk mencapai hasil lompatan yang maksimal. Untuk itu perlu penguasaan teknik lompatan yang benar serta mematuhi peraturannya guna mencapai prestasi dalam lompat jauh. Menurut Benhart (1993:45),

Unsur-unsur dasar bagi suatu prestasi pada lompat jauh dan pembangunannya adalah :

1) Faktor-faktor jasmani (fisik) : terutama kecepatan, tenaga lompat, dan tujuan yang diarahkan pada ketrampilan.

2) Faktor-faktor teknik : ancang-ancang persiapan lompat, perpindahan fase melayang dan pendaratan.

Lompat jauh memiliki empat unsur yang sangat penting yaitu : awalan, tolakan atau tumpuan, melayang dan mendarat. Semua gerakan-gerakan itu 


\section{PERBEDAAN PENGARUH LATIHAN PLIOMETRIK DOUBLE LEG BOUND DAN ALTERNATE LEG BOUND TERHADAP KEMAMPUAN LOMPAT JAUH GAYA JONGKOK PADA ATLET PUTRA PASI SUKOHARJO TAHUN 2020 \\ (Iwan Arya Kusuma,,Fatchurrahman Ramadhan)}

merupakan satu kesatuan urutan gerak lompat jauh yang tidak terputus dalam pelaksanaannya.

\section{b. Teknik Gerakan Lompat Jauh Gaya Jongkok}

Gaya lompat jauh merupakan gerakan atau sikap tubuh yang dilakukan pada saat pelompat melayang diudara. Pada saat melayang ini seorang pelompat perlu menjaga keseimbangan tubuh dengan baik dan kalau bisa membuat gerakan guna memperoleh lompatan yan maksimal. Lompat jauh gaya jongkok merupakan gaya yang paling mudah dilakukan terutama bagi anak-anak sekolah. Aip Syarifuddin (1992:93) menyatakan “Lompat jauh gaya jongkok tidak banyak gerakan yang dilakukan pada saat melayang diudara dibandingkan dengan gaya yang lainnya. Konsentrasi atlet yang perlu diperhatikan pada gaya jongkok terletak pada membungkukkan badan dan menekuk kedua lutut dan menjulurkan kedua kaki kedepan dan kedua lengan tetap kedepan untuk mendarat."

\section{METODOLOGI PENELITIAN}

Metode penelitian adalah cara yang digunakan oleh peneliti dalam mengumpulkan data penelitian (Suharsimi Arikunto, 2006:160). Metode diperlukan dalam pelaksanaan suatu penelitian. Metode penelitian memberikan garis-garis yang cermat dan mengajukan syarat-syarat yang benar, maksudnya menjaga agar memperoleh hasil yang sesuai dan dapat dipertanggung jawabkan secara ilmiah. Penetapan metode penelitian dipengaruhi oleh objek penelitian. Sehingga metode yang digunakan dalam penelitian ini adalah metode eksperimen.

Menurut Suharsimi Arikunto (2010:9), metode eksperimen adalah suatu cara untuk mencari hubungan sebab akibat (hubungan kasual) antara dua faktor yang sengaja ditimbulkan oleh peneliti dengan mengeliminisasi atau mengurangi atau menyisihkan faktor-faktor lain yang mengganggu. Penelitian ilmiah yang digunakan sebagai metodologi penelitian harus tepat dan mengarah pada tujuan 


\section{PERBEDAAN PENGARUH LATIHAN PLIOMETRIK DOUBLE LEG BOUND DAN ALTERNATE LEG BOUND TERHADAP KEMAMPUAN LOMPAT JAUH GAYA JONGKOK PADA ATLET PUTRA PASI SUKOHARJO TAHUN 2020 \\ (Iwan Arya Kusuma,,Fatchurrahman Ramadhan)}

penelitian, sehingga penelitian memperoleh hasil yang sesuai dengan tujuan penelitian. Metode penelitian adalah syarat mutlak dalam suatu penelitian, berbobot atau tidaknya mutu penelitian tergantung pada pertanggung jawaban metodologi penelitian, maka diharapkan dalam penggunaan metodologi penelitian harus tepat dan mengarah pada tujuan penelitian. Desain penelitian yang digunakan dalam penelitian ini adalah pre-test and post-test group.

\section{HASIL PENELITIAN DAN PEMBAHASAN}

\section{Perbedaan Pengaruh Latihan Pliometrik Doubel Leg Bonddengan Latihan} Pliometrik Alternate Leg Bound terhadap Hasil Lompat Jauh Gaya Jongkok

Berdasarkan hasil analisis data yang dilakukan sebelum diberi perlakuan, diperoleh nilai $\mathrm{t}$ antara tes awal pada kelompok 1 dan kelompok $2=0.121$, sedangkan ttabel $=2.145$. Ternyata thit $<$ ttabel, yang berarti hipotesis nol diterima. Dengan demikian dapat disimpulkan bahwa, kelompok 1 dan kelompok 2 sebelum diberi perlakuan dalam keadaan seimbang atau tidak terdapat perbedaan kemampuan lompat jauh gaya jongkok. Hal ini artinya, antara kelompok 1 dan 2 berangkat dari titik tolak kemampuan lompat jauh gaya jongkok yang sama. Apabila setelah diberi perlakuan terdapat perbedaan, hal ini karena adanya perbedaan perlakuan yang diberikan.

Berdasarkan hasil pengujian perbedaan tes awal dan tes akhir pada kelompok 1 diperoleh nilai sebesar $=2.286$ sedangkan ttabel $=2.145$. Ternyata thitung $>$ ttabel $5 \%$, yang berarti hipotesis nol ditolak. Dengan demikian dapat disimpulkan bahwa, terdapat perbedaan yang signifikan antara hasil tes awal dan tes akhir pada kelompok 1 . Hal ini artinya, kelompok 1 memiliki peningkatan kemampuan lompat jauh gaya jongkok yang disebabkan oleh perlakuan yang diberikan yaitu, pembelajaran lompat jauh gaya jongkok dengan pendekatan bermain.

Berdasarkan hasil pengujian perbedaan tes awal dan tes akhir pada kelompok 2 diperoleh nilai sebesar $=4.604$, sedangkan ttabel $=2.145$. Ternyata thitung >ttabel, yang berarti hipotesis nol ditolak. Dengan demikian dapat 
(Iwan Arya Kusuma,,Fatchurrahman Ramadhan)

disimpulkan bahwa terdapat perbedaan yang signifikan antara basil tes awal dan tes akhir pada kelompok 2. Hal ini artinya, kelompok 2 memiliki peningkatan kemampuan lompat jauh gaya jongkok yang disebabkan oleh perlakuan yang diberikan, yaitu pembelajaran lompat jauh gaya jongkok dengan pendekatan drill.

Berdasarkan hasil pengujian perbedaan yang dilakukan pada data tes akhir antara kelompok 1 dan kelompok 2 diperoleh basil thitung sebesar 2.434, sedangkan ttabel pada taraf signifikansi 5\% sebesar 2.145. Berdasarkan basil tersebut dapat disimpulkan bahwa, terdapat perbedaan yang signifikan antara tes akhir pada kelompok 1 dan tes akhir kelompok 2. Dengan demikian hipotesis yang menyatakan, ada perbedaan pengaruh antara pendekatan pembelajaran bermain dan drill terhadap kemampuan lompat jauh gaya jongkok pada atlet putra PASI Sukoharjo tahun 2020, dapat diterima kebenarannya.

\section{Perbedaan Pengaruh Latihan Pliometrik Doubel Leg Bonddengan Latihan} Pliometrik Alternate Leg Boundterhadap Hasil Lompat Jauh Gaya Jongkok

Berdasarkan basil penghitungan presentase peningkatan kemampuan lompat jauh gaya jongkok diketahui bahwa, kelompok 1 memiliki nilai presentase peningkatan kemampuan lompat jauh gaya jongkok sebesar 9.933\%. Sedangkan kelompok 2 memiliki peningkatan kemampuan lompat jauh gaya jongkok sebesar 3.250\%. Berdasarkan hasil tersebut dapat disimpulkan bahwa, kelompok 1 memiliki presentase peningkatan kemampuan lompat jauh gaya jongkok yang lebih besar dari pada pada kelompok 2. Dengan demikian hipotesis yang menyatakan, pendekatan pembelajaran bermain lebih baik pengarahannya daripada pendekatan drill terhadap kemampuan lompat jauh gaga jongkok pada atlet putra PASI Sukoharjo tahun 2020, dapat diterima kebenaramiya. 
(Iwan Arya Kusuma,,Fatchurrahman Ramadhan)

\section{KESIMPULAN DAN SARAN}

\section{a. Kesimpulan}

Berdasarkan basil penelitiandan hasil analisis data yang telahdilakukan, ternyata hipotesis yang diajukan dapat diterima. Dengan demikian dapat diperoleh simpulan sebagai berikut:

1. Ada Perbedaan pengaruh latihan pliometrik doubleleg bound dengan latihan pliometrik alternate leg boundterhadap kemampuan lompat jauh gaya jongkokpada atletputra PASI Sukoharjotahun 2020, dengan nilai perhitungan thit $2.434>$ ttabel2.145 pada taraf signifikasi 5\%.

2. Latihan pliometrik alternate leg bound lebih baik pengaruhnya daripada latihan pliometrik double leg bound kemampuan lompat jauh gaya jongkok pada atlet putra PASI Sukoharjo tahun 2020. Kelompokl (kelompok yang mendapat perlakuan pliometrik alternate leg bound) memiliki peningkatan sebesar $9.933 \%$. Sedangkan kelompok 2 (kelompok yang mendapat latihan pliometrik double leg bond memiliki peningkatan sebesar 3.250\%.

\section{b. Saran}

Berdasarkan hasil penelitian ini, saran-saran yang dapat dikemukakan pada atlet putra PASI Sukoharjo tahun 2020 sebagai berikut:

1. Dalam membelajarakan Penjas hendaknya guru memiliki kreativitas dan inovatif, sehingga pembelajaran pelatih tidak monoton.

2. Hendaknya sekolah menyediakan dan menambah sarana pembelajaran Penjas, sehingga kendala-kendala dalam latihan dapat diatasi.

3. latihan pliometrik double leg bound dapat diterapkan untuk meningkatkan kemampuan cabang olahraga lainnya. 
(Iwan Arya Kusuma,,Fatchurrahman Ramadhan)

\section{DAFTAR PUSTAKA}

Adang Suherman dan Agus Mahendra. 2001. Menuju Perkembangan Menyeluruh Menyiasati Kurikulum Pendidikan Jasmani Menengah Umum. Jakarta: Depdiknas. Direktorat Jendral Pendidikan Dasar menengah Bekerj asama dengan Direktorat Jenderal Olahraga.

Adang Suherman, Yudha M. Saputra \& Yudha Hendravana. 2001 . Pembelajaran Atletik Pendekatan Permainan \& Kompetensi untuk Siswa SMU SMK. Jakarta: Depdikbud. Direktorat Jenderal Pendidikan Dasar dan Menengah. Bagian Proyek Penataran Guru SLTP Setara D-I1I.

Aip Syarifudin. 1992. Atletik. Jakarta: Depdikbud. Dirjendikti. Proyek Pembinaan Tenaga Kependidikan.

Andi Suhendro. 2007. Dasar-Dasar Kepeketihan. Jakarta: Universitas Terbuka.

H.J. Gino, Suwarni, Suripto, Maryanto dan Sutijan. 1998. Belajar dan. Pembelajaran II. Surakarta; UNS Press.

M. Furcion H. 2006. Mendidik Anak dengan Bermain. Surakarta : Program Studi D-2 Pendidikan Jasmani. JPOK FKIP UNS.

Mochamad Djumidar A. Widya. 2004. Belajar Berlatih Gerak-Gerak Dasar Atletik dalam Bermain. Jakarta. PT. Rajagrafinio Persada.

M. Sobry Sutikno. 1992. Tes dan Pengukuran. Surakarta : UNS Press.

2001. Tes dan Pengukuran dalam Pendidian Jasmani. Surakarta UNS Press. 